\title{
Dysgonia rogenhoferi (BoHATsCH, 1880) (Lepidoptera, Erebidae) in the Danube Delta (Romania): Westernmost record in Europe
}

\author{
Levente CsuKÁs, Levente SzÉKELY \& Vlad DinCǍ
}

\begin{abstract}
Summary: Dysgonia rogenhoferi (ВонатsсH, 1880) is recorded for the first time in Romania based on material collected in the Danube Delta (Chilia Veche, Tulcea County). This species has likely recently reached the Danube Delta, but it remains to be seen if it will develop stable populations in the region. Two hypotheses are formulated about the presence of this species in the Danube Delta: (1) Accidental introduction (involuntary transport by ships navigating the Danube), and (2) natural expansion. The latter is regarded as the most likely, based on recent faunistic data from Eastern Europe. The specimens from the Danube Delta represent the westernmost records of this species in Europe, approximately $600 \mathrm{~km}$ west of the most recent site discovered in south-eastern Ukraine.
\end{abstract}

Rezumat: Dysgonia rogenhoferi (BоHATSCH, 1880) este semnalată pentru prima dată în fauna României, pe baza unui material colectat în Delta Dunării (Chilia Veche, Județul Tulcea). Cel mai probabil, această specie a pătruns recent în Delta Dunării, însă rămâne de văzut dacă va dezvolta populații stabile în regiune. Sunt formulate două ipoteze cu privire la prezența acestei specii în Delta Dunării: (1) introducere accidentală (transport involuntar cu nave care tranzitează Dunărea), și (2) expansiune naturală. Cea din urmă este considerată cea mai probabilă, pe baza datelor faunistice recente din estul Europei. Exemplarele din Delta Dunării reprezintă cele mai vestice semnalări ale aceste specii în Europa, fiind situate la aproximativ $600 \mathrm{~km}$ vest față de locaţia recent descoperită în sud-estul Ucrainei.

Key words: Dysgonia rogenhoferi, Danube Delta, Romania, Europe, distribution.

\section{Introduction}

Dysgonia rogenhoferi (BoHATsCH, 1880) is an Irano-eremic species known to occur in the Levant, Iraq, Arabia, northern Iran, Azerbaijan and Central Asia (Turkmenistan, Uzbekistan, Pakistan) (GOATER et al. 2003). The species has also been recently recorded ( 1 female, 6 July 2018) from eastern Turkey,

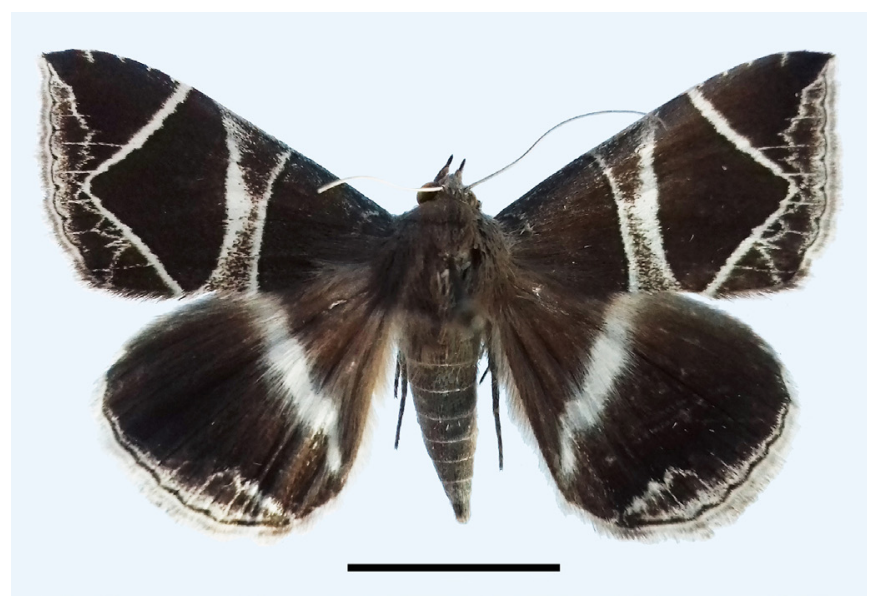

Fig. 1. Dysgonia rogenhoferi, 27.VI.2020, Romania, Tulcea county, Danube Delta, Chilia Veche, $3 \mathrm{~m}$. Scale bar is $10 \mathrm{~mm}$. (Photo: L. Csukás) near the Armenian border (SEVEN et al. 2019). Near the eastern borders of Europe, D. rogenhoferi has been reported from various sites in the south-western part of the Russian Federation (Dagestan, Kalmykia) (e.g. Poltavsky and Ilyina 2002, 2017, AbDURakhmanov 2012, AbDURAKHMANOV et al. 2013).

In Europe, the species is known based on very few specimens originating from the Astrakhan region of southern Russia (LvOvsKy 1971, LASTUCHIN 2009, Fibiger et al. 2010, NuPPONEN and Fibiger 2012). Interestingly, a very recent record (1 male, 21 August 2019) from south-eastern Ukraine (northern shore of the Sea of Azov) has considerably extended the potential distribution of $D$. rogenhoferi on the continent (SUCHKOV and GERYAK 2019).

\section{Results}

Material: 2 specimens, 27.VI.2020, Romania, Tulcea county, Danube Delta, Chilia Veche, $3 \mathrm{~m}$ $\left(45.4252^{\circ} \mathrm{N}, 29.2912^{\circ} \mathrm{E}\right)$, on the Chilia branch of the Danube (leg \& coll. Levente Csukás) (Figs 1, 2a,b).

Apart from the two specimens sampled, approximately ten more specimens have been observed during the same evening. The material was collected using a $250 \mathrm{~W}$ mercury vapor bulb placed in 

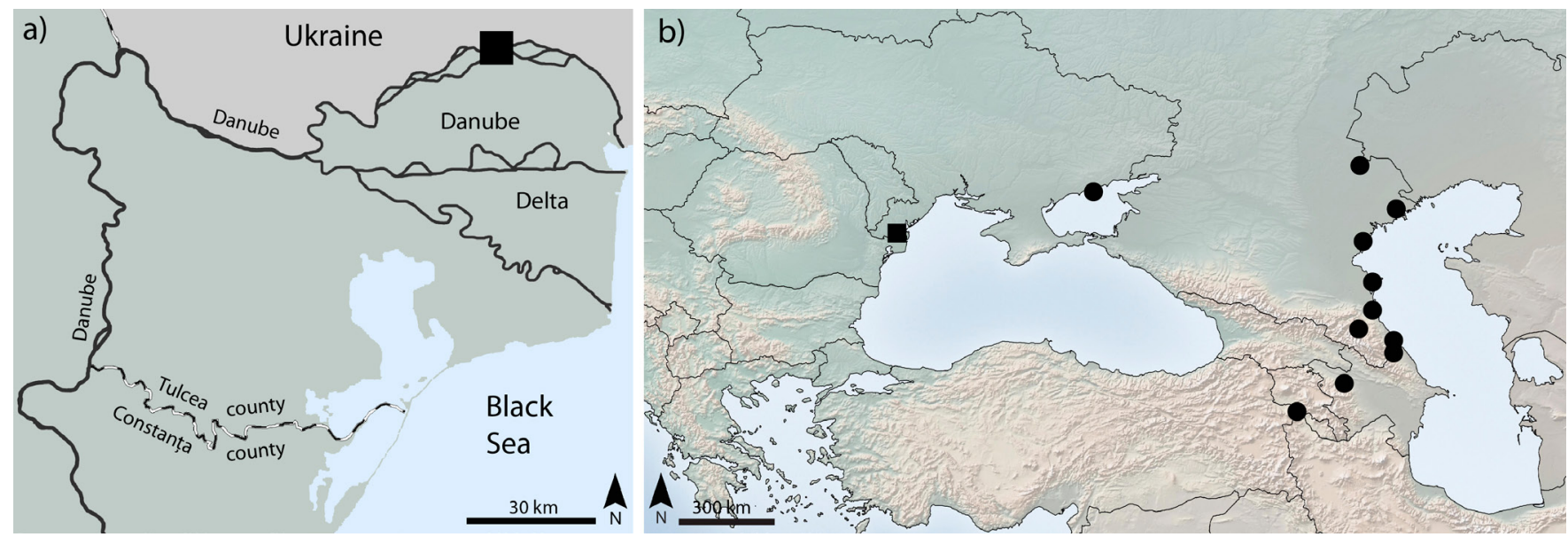

Fig. 2. a) Record of Dysgonia rogenhoferi (black square) in the Danube Delta (Tulcea county, Romania). b) Distribution of D. rogenhoferi around the Black Sea and the western coast of the Caspian Sea. Black square, record from the Danube Delta (Romania); black dots, records outside Romania.

front of a white house wall, only a few meters away from the shores of the Danube. The wingspan of the collected specimens is of $38 \mathrm{~mm}$.

\section{Discussion}

Our records from the Danube Delta greatly extend westwards the potential range of D. rogenhoferi. The collection site (Chilia Veche) (Fig. 2a) is situated approximately $1400 \mathrm{~km}$ west of the Astrakhan region, which was, until very recently, known as the only European area of occurrence of the species (see the Introduction). Chilia Veche also lies circa $600 \mathrm{~km}$ west of the very recent record from south-eastern Ukraine (SuCHKOv and GeRYAK 2019) (Fig. 2b).

This species is, most likely, a recent member of the entomofauna of the Danube Delta because the region has been fairly well studied from a lepidopterological point of view (e.g. SzÉKELY 2006 and references therein). According to Wiltshire (1951), the larvae of $D$. rogenhoferi feed on Tamarix sp. (Tamaricaceae) and a representative of this genus ( $T$. ramosissima LEDEBOUR, salt cedar) is relatively widespread in the Danube Delta and other parts of (mostly) southern and eastern Romania (OPREA 2005). However, it is currently unclear if $D$. rogenhoferi was accidentally introduced to the Danube Delta (e.g. by ships navigating the Danube), or if it has naturally expanded its range. Although further research is needed to ascertain whether the species has established stable populations in the Danube Delta, we suspect that it has been naturally expanding westwards. This hypothesis is, to some extent, supported by the recent records from south-eastern Ukraine (SUCHKOV and GERYAK 2019) and eastern Turkey (SEven et al. 2019).

Dysgonia rogenhoferi can be reliably identified based on wing pattern and can be readily differentiated from the other two congenerics known in Europe, Dysgonia algira (Linnaeus, 1767) and Dysgonia torrida (GUENÉE, 1852). The most obvious diagnostic feature is the presence of a white V-shaped line, the tip of which gets close to the distal margin of the forewing (Fig. 1).

The species is apparently multivoltine in the southern parts of its range (WILTSHIRE 1951), but its phenology in the northern range is insufficiently known in our opinion. For example, in Dagestan and the Astrakhan region, records range from mid-June to mid-September (e.g. Poltavsky and ILyina 2002, 2017, Lastuchin 2009, NupPonen and Fibiger 2012). The specimens from the Danube Delta were collected on 27 June, while the male from southeastern Ukraine was found on 21 August. Further data are needed to determine whether the species is single or multi-brooded in such areas.

In desert regions of the southern range, the species is typically found in oases (GOATER et al. 2003), while in Europe and other parts of the northern range it seems to be associated with deltas (Volga Delta, Danube Delta) and other sandy coastal or riverside ecosystems, as well as sandy deserts (e.g. PoltaVsky and Ilyina 2002, 2017, LASTUChIN 2009, Abdurakhmanov 2012, Nupponen and Fibiger 2012, this study).

In conclusion, $D$. rogenhoferi represents an unexpected addition to the Lepidoptera fauna of Romania and currently marks the western limit of distribution of this species in Europe. While current data suggest it is locally relatively common in the Danube Delta, further research is needed to ascertain whether the species has developed stable populations in the region and/or if it will further expand in Romania. Although the possibility of a humanmediated expansion cannot be fully excluded, we hypothesize that the species has naturally expanded its range to the Danube Delta, where suitable habitats, as well as the reported larval food plant (Tamarix sp.) are present. If this hypothesis is correct, then D. rogenhoferi represents yet another example of southern or eastern species that seem to be recently 
reaching/expanding into the Romanian territory, such as Grammodes bifasciata (Petagna, 1787), Schrankia balneorum (AlphÉrAKy, 1880), Acontia candefacta HÜBNER, [1831]), Leucania punctosa (TREITSCHKE, 1825 ) etc. (RÁkosy and Mihai 2011, SzÉKely et al. 2011, SZÉKelY and DinCĂ 2012, SZÉKELY 2016, MANCI et al. 2018).

\section{Acknowledgements}

We thank Sergey Suchkov (Melitopol, Ukraine) and Yevgeniy Khalaim (Odessa, Ukraine) for information regarding the presence of D. rogenhoferi in Ukraine. We thank László Rákosy for discussions during the preparation of the manuscript. Support for this research was provided by the Academy of Finland to Vlad Dincă (Academy Research Fellow, decision no. 328895).

\section{References}

Abdurakhmanov A.G. (2012) Contribution to the species composition of Noctuidae (Lepidoptera, Noctuidae) of the Chechen Island, Dagestan sector of the Caspian Sea. In: Proceedings of the XIV Congress of the Russian Entomological Society, Saint Petersburg. pp. 4. (in Russian).

Abdurakhmanov G.M., Abdurakhmanov A.G., Kurbanova N.S., Melikova N.M., Ivanushenko U.U and KuRAmagomedov B.M. (2013) Species composition and geographical distribution of the noctuid moths (Lepidoptera, Noctuidae) of coastal and island ecosystems of the North-Western Caspian Sea. The South of Russia: ecology, development 2: 26-48 (in Russian).

Fibiger M., Ronkay L., Yela J.L. and Zilli A. (2010) Rivulinae - Phytometrinae, and Micronoctuidae, including supplement to Noctuidae Europaeae, vols 1-11. Noctuidae Europaeae vol. 12. Sorø, Entomological Press.

Goater B., Ronkay L. and Fibiger M. (2003) Catocalinae \& Plusiinae. Noctuidae Europaeae vol. 10. Sorø, Entomological Press.

LASTUCHIN A. (2009) [Autumn spectrum of moth flight in the Volga Delta, on the territory of the Astrakhan nature reserve]. Scientific proceedings of the state reserve "Prisurskiy" 21: 12-22. (in Russian).

Lvovsky A.L. (1971) [Materials on the fauna of Macrolepidoptera from the Astrakhan Region]. Entomologicheskoye Obozrenie, 50: 800-810 (in Russian).

Manci C.O., Sitar C. and Rákosy L. (2018) Schrankia balneorum (Alphéraky, 1880) (Lepidoptera, Erebidae) -
The first records for Romania. Entomologica Romanica 22: 57-59.

NUPPONEN K. and Fibiger M. (2012) Additions to the checklist of Bombycoidea and Noctuoidea of the VolgoUral region. Part II. (Lepidoptera: Lasiocampidae, Erebidae, Nolidae, Noctuidae). Nota Lepidopterologica 35(1): 33-50.

Oprea A. (2005) Lista critică a plantelor vasculare din România. [Critical list of vascular plants in Romania]. Iași: Editura Universității “Alexandru Ioan Cuza” (in Romanian).

Poltavsky A.N. and Ilyina E.V. (2002) The Noctuidae (Lepidoptera) of the Daghestan Republic (Russia). Phegea 30(1): 11-36.

PoltaVsky A.N. and ILYina E.V. (2017) [New and rare species of moths (Lepidoptera: Noctuoidea) of Dagestan. In: Biological diversity - fundamental for sustainable development]. Proceedings of the international scientific and practical conference, Grozny - Makhachkala. pp. 61-66. (in Russian).

Rákosy L. and Minai C. (2011) Grammodes bifasciata (Petagna, 1787) şi Acontia (Emmelia) candefacta (Hübner, [1831]) (Lepidoptera, Noctuidae) specii nou pătrunse în fauna României. [Grammodes bifasciata (Petagna, 1787) and Acontia (Emmelia) candefacta (Hübner, [1831]) (Lepidoptera, Noctuidae), newly acquired species in the Romanian fauna]. Buletin de Informare Entomologică 22: 11-13 (in Romanian).

Seven E., GözÜAÇıK C. and Aykut E. (2019) A review of genus Dysgonia Hübner (Lepidoptera, Erebidae, Erebinae) from Turkey with distinctive external and genital morphological characters and a new species for the Turkish fauna. Transactions American Entomological Society 145: 385 - 393.

SuchKov S. I. and GerYaK Yu. M. (2019) On the distribution of Noctuoid moths (Lepidoptera: Noctuoidea) in the North-Western Pryazovia and adjacent regions of the steppe zone of Ukraine. The Kharkov Entomological Society Gazette 27(2): in press.

SzÉKeLY L. (2006) Lepidopterele din Delta Dunării. [The Lepidoptera of the Danube Delta]. Săcele, Disz-Tipo. (in Romanian).

SzÉKELY L. (2016) New and rare macrolepidoptera (Insecta) from Romanian Dobrogea (south-east Romania). Travaux du Muséum National d'Histoire Naturelle «Grigore Antipa» 59(2): 195-230.

SzÉKELY L. and DinCÃ V. (2012) Leucania punctosa (Lepidoptera: Noctuidae), a new species in the Romanian fauna. Phegea 40(4): 87-91.

SZÉKELY L., DinCĂ V. and JUHÁsz I. (2011) Macrolepidoptera from the steppes of Dobrogea (south-eastern Romania). Phegea 39(3): 85-106.

WiLtshiRe E.P. (1951) A year on Tigris Island. Journal of the Bombay Natural History Society 49(4): 637-660.
Levente CsuKás

Str. Fodorkert, 52 A, Miercurea Ciuc, 530201, Jud. Harghita, Romania

E-mail: csukas@isjhr.eduhr.ro
Levente SzÉKeLY

Bd. George Moroianu 29, Săcele,

505600, Jud. Brașov, Romania

E-mail: levi.szekely@gmail.com
Vlad Dinc

Ecology and Genetics Research Unit,

University of Oulu, PO Box 3000,

Oulu, 90014, Finland

E-mail: vlad.e.dinca@gmail.com

Received: 31.08 .2020

Accepted: 15.09.2020

Published online: 30.09 .2020

Published: 31.12.2020

Online article number: ER24202005

doi: 10.24193/entomolrom.24.5 